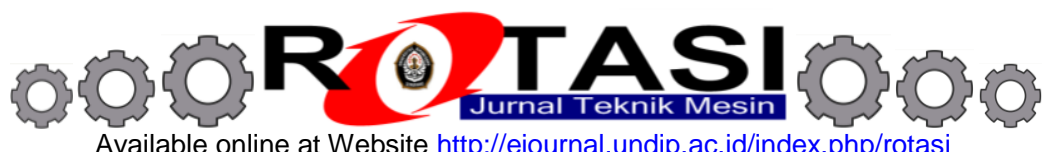

Available online at Website http://ejournal.undip.ac.id/index.php/rotasi

\title{
STUDI PERFORMANSI TEXTURED BEARING DENGAN PELUMAS NON-NEWTONIAN DENGAN MEMPERTIMBANGKAN SLIP DAN KAVITASI
}

\author{
*M. Tauviqirrahman, B. Muthik, R. Risky \\ Departemen Teknik Mesin, Fakultas Teknik, Universitas Diponegoro \\ Jl. Prof. Sudharto, SH., Tembalang-Semarang 50275, Telp. +62247460059 \\ *E-mail: mohammad.tauviqirrahman@ft.undip.ac.id
}

\begin{abstract}
ABSTRAK
Saat ini, dalam dunia medis telah dikembangkan berbagai peralatan biomekanik yang dibuat untuk memperbaiki kualitas kesehatan manusia. Dalam peralatan tersebut, bearing merupakan salah satu elemen-elemen mesin yang memiliki fungsi vital. Hal ini dikarenakan bearing berfungsi membatasi gerak relatif antara dua atau lebih komponen mesin agar selalu bergerak pada arah yang diinginkan. Dengan menjaga fungsi pelumasan pada bearing, maka putaran bisa berlangsung secara halus dan aman, sehingga diharapkan pada akhirnya nanti peralatan kesehatan tersebut dapat mempunyai umur pakai yang lebih panjang. Penelitian-penelitian tentang pelumasan pada bearing saat ini banyak mengasumsikan pelumas bersifat Newtonian. Dalam kenyataannya, pelumas pada bearing di tingkat lapangan memiliki karakteristik non-Newtonian. Oleh karena itu, dalam penelitian kali ini, bearing dengan pelumas non Newtonian akan dianalisa lebih lanjut dengan menggunakan CFD (computational fluid dynamic). Permukaan kontak pada bearing akan dimodifikasi dengan tekstur dan slip untuk meningkatkan performansi pelumasan. Kedalaman tekstur divariasikan sebesar 0.1 dan 0.75 kali ketebalan film pelumas. Daya dukung beban dan gesekan menjadi dua parameter utama performansi pelumasan yang akan dianalisa. Dalam tulisan ini, perbandingan hasil antara analisa yang mempertimbangkan model kavitasi dengan yang tidak, menjadi pokok kajian. Hasil simulasi menunjukkan bahwa terdapat perbedaan hasil numerik antara yang mempertimbangkan kavitasi dan yang tidak sampai dengan $20 \%$. Selain itu, dengan memberikan slip pada tekstur dapat meningkatkan performansi daya dukung beban sebesar $300 \%$ dengan menjaga gesekan tetap kecil. Hasil penelitian kali ini dapat dijadikan sebagai langkah awal untuk memperbaiki kualitas performansi textured bearing yang berpelumas non Newtonian.
\end{abstract}

Kata kunci: CFD (computational fluid dynamic), kavitasi, non Newtonian, pelumasan, slip, tesktur

\section{PENDAHULUAN}

Bearing merupakan elemen mesin yang dirancang untuk menahan beban eksternal dengan mengandalkan gerak relatif antara dua permukaan yang sedang kontak. Pemberian pelumas dapat menghindari kontak langsung antar permukaan sehingga keausan (wear) dapat dihindari [1]. Adanya gradien tekanan yang terjadi dalam clearance menghasilkan daya dukung beban. Selain itu, dikarenakan adanya daerah konvergen-divergen dalam bearing, fenomena kavitasi sangat mungkin terjadi. Dari sudut pandang numerik, fenomena kavitasi dapat dimodelkan dan dikategorikan ke dalam beberapa kelompok, yaitu dengan menggunakan teori Sommerfeld, teori Half-Sommerfeld, teori Reynolds, atau dengan menggunakan kekekalan massa. Dua teori yang pertama merupakan pendekatan yang kasar karena tidak mencerminkn fenomena fisik yang nyata [2].

Dari studi pustaka, dapat diketahui bahwa hanya sedikit sekali tulisan yang menjelaskan hasil penelitian terkait dengan simulasi numerik pada bearing dengan pelumas non Newtonian baik yang mempertimbangkan model kavitasi maupun yang tidak. Mishra [3] mengembangkan metode numerik dengan memecahkan persamaan Reynolds dan energi untuk menginvestigasi pengaruh journal misalignment dengan pelumas non Newtonian. Untuk menjelaskan karakteristik pelumas dalam daerah kavitasi, metode Elrod [4] telah digunakan. Yadav dan Sharma [5] telah menganalisa pengaruh parameter tekstur terhadap karakteristik statik dan dinamik pada bearing. Lin dkk [6] telah mempelajari pengaruh non-Newtonian terhadap batas stabilitas bearing melalui analisis transien non-linear. Pratomo dkk [7] telah menginvestigasi pengaruh kombinasi tekstur dan kondisi batas slip terhadap tekanan hidrodinamik. Persamaan Reynolds yang sudah dimodifikasi untuk pelumasan dengan karaktristik non-Newtonian power-law telah dikembangkan. Hasil simulasi mereka menunjukkan bahwa daya dukung beban maksimum dicapai ketika kedalam tekstur sama dengan ketebalan film. Meskipun demikian, dalam penelitian mereka kondisi batas Reynolds digunakan untuk memodelkan kavitasi. Penelitian berikutnya, Tauviqirrahman dkk [8] dengan menggunakan pendekatan numerik persamaan kekekalan massa untuk memodelkan kavitasi telah mengadakan penelitian tentang performansi pelumasan hidrodinamika pada kasus bearing bertekstur tunggal. Dalam penelitian terbaru, Khatri dan Sharma [9] telah melakukan studi perbandingan antara permukaan yang bertekstur dengan yang tidak bertekstur pada jounal bearing. Dalam studi mereka, analisis dilakukan dengan menggunakan teori Reynolds yang hasilnya masih diragukan karena kemungkinan adanya efek inersia. 
Berdasarkan penelusuran pustaka seperti yang telah dijelaskan, dapat diambil kesimpulan bahwa penelitian karakteristik bearing dengan pelumas non Newtonian yang mempertimbangkan model kavitasi masih sangat sedikit. Bermula dari pemahaman bahwa model kavitasi memiliki dampak yang sangat besar terhadap hasil analisis bearing, maka metode numerik berbasis model CFD (computational fluid dynamic) akan dikembangkan. Selain itu, UDF (userdefined function) juga dibuat untuk memodelkan kondisi batas slip pada permukaan. Dalam penelitian kali ini, pengaruh kedalaman tekstur akan diteliti baik dengan kondisi batas slip maupun tidak. Selain itu, pengaruh pemodelan kavitasi terhadap prediksi perhitungan performansi pelumasan (daya dukung beban dan gesekan) juga dilakukan.

\section{PERSAMAAN UMUM}

Persamaan yang digunakan adalah persamaan Navier-Stokes dan kontinuitas yang dipecahkan dengan menggunakan metode volume hingga. Persamaan tersebut mengasumsikan densitas dan viskositas konstan, tanpa melibatkan gaya bodi. Kondisi steady dan pemecahan dalam arah dua dimensi ( $x$ dan $z$ ) juga digunakan. Persamaan Navier-Stokes dan kontinuitas diekspresikan sebagai berikut:

$$
\begin{aligned}
& \rho(\mathbf{u} \bullet \nabla) \mathbf{u}=-\nabla p+\eta \nabla^{2} \mathbf{u} \\
& \nabla \bullet \mathbf{u}=0
\end{aligned}
$$

Ketersediaan pelapis berjenis hydrophobic memungkinkan untuk memodifikasi komponen bearing agar memiliki performansi sesuai dengan yang diinginkan. Penerapan hydrophobic ini menyebabkan pelumas akan mengalami slip pada permukaan bearing. Kondisi ini terbukti dapat menurunkan gaya gesekan baik secara numerik [10] maupun eksperimen [11], [12]. Ketika pelumas mengalami slip di sepanjang permukaan solid-liquid, panjang slip $\beta$ sebagai ukuran tingkap slip suatu pelumas dinyatakan dengan hubungan sebagai berikut:

$$
u_{s}=\left.\beta \frac{\partial u}{\partial z}\right|_{\text {permukaan }}
$$

dimana $u_{\mathrm{s}}$ mengindikasikan kecepatan slip pada permukaan hydrophobic, $\beta$ panjang slip, dan $\partial u /\left.\partial z\right|_{\text {dinding }}$ sebagai laju geser permukaan. Dalam penelitian ini, panjang slip pada permukaan hydrophobic diasumsikan uniform dalam ruang dengan $\beta$ sebesar $1 \mu \mathrm{m}$ [11].

Dalam penelitian ini, karakteristik non-Newtonian dimodelkan dengan skema model power-law. Artinya adalah bahwa tegangan geser $\tau$ merupakan fungsi tingkat dari laju regangan $\dot{\gamma}$. Hubungan tegangan-regangan ini dapat dimodelkan sebagai berikut:

$$
\tau=m(\dot{\gamma})^{n}
$$

Dalam kavitasi, transfer massa liquid-vapor (evaporasi dan kondensasi) dimodelkan dengan menggunakan persamaan vapor transport [13] sebagai berikut:

$$
\frac{\partial}{\partial t}\left(\alpha_{v} \rho_{v}\right)+\nabla \cdot\left(\alpha_{v} \rho_{v} \mathrm{v}\right)=R_{g}-R_{c}
$$

dimana $\alpha_{v}$ adalah fraksi volume vapour dan $\rho_{v}$ adalah densitas vapour. $R_{g}$ dan $R_{c}$ merujuk kepada transfer massa antara fasa liquid dan fasa vapour dalam kavitasi. Untuk model Zwart-Gelber-Belamri, bentuk akhir persamaan kavitasi adalah sebagai berikut [14]:

Jika $p \leq p_{v}$,

$$
\text { maka } R_{g}=F_{\text {evap }} \frac{3 \alpha_{\text {nuc }}\left(1-\alpha_{v}\right) \rho_{v}}{R_{\mathrm{B}}} \sqrt{\frac{2}{3} \frac{\mathrm{P}_{v}-\mathrm{P}}{\rho_{\ell}}}
$$

Jika $p \geq p_{v}$,

$$
\text { maka } R_{c}=F_{\text {cond }} \frac{3 \alpha_{v} \rho_{v}}{R_{\mathrm{B}}} \sqrt{\frac{2}{3} \frac{\mathrm{P}-\mathrm{P}_{v}}{\rho_{\ell}}}
$$


dimana $F_{\text {evap }}=$ koefisien evaporasi $=50, F_{\text {cond }}=$ koefisien kondensasi $=0.01, R_{B}=$ radius gelembung-gelembung udara $=10^{-6} \mathrm{~m}, \alpha_{\text {nuc }}=$ fraksi volume situs nukleasi $=5 \times 10^{-4}, \rho_{l}=$ densitas liquid dan $p_{v}=$ tekanan vapour.

\section{METODE PENELITIAN}

\subsection{Skema bearing dengan tekstur}

Gambar 1 menyajikan geometri model tiga dimensi textured bearing. Sedangkan Gambar 2 menyajikan skema representasi textured bearing beserta besaran fisik yang ada. Pada bearing jenis ini, tekstur sengaja diberikan di bagian inlet pada permukaan yang diam untuk mendapatkan performansi pelumasan yang baik sesuai dengan hasil penelitian terkini [15]. Pada bearing ini ketebalan film atau ketinggian fluida memisahkan dua permukaan. Ketinggian fluida ini merupakan fungsi linier dari $x$ (Persamaan 8 ).

$$
h(x)=h_{1}-\frac{\left(h_{i}-h_{o}\right)}{L} x
$$

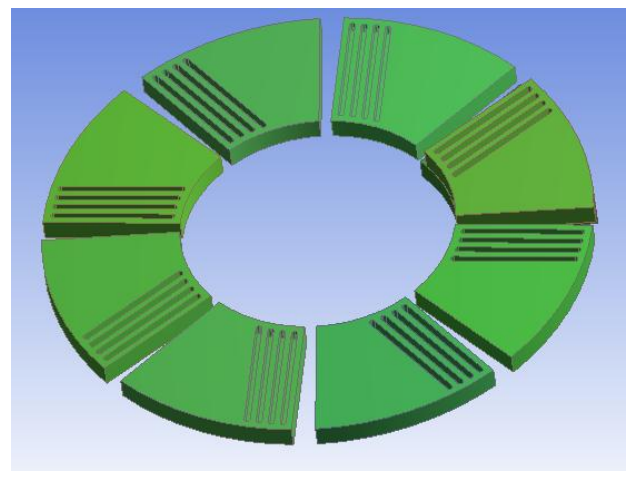

(a)

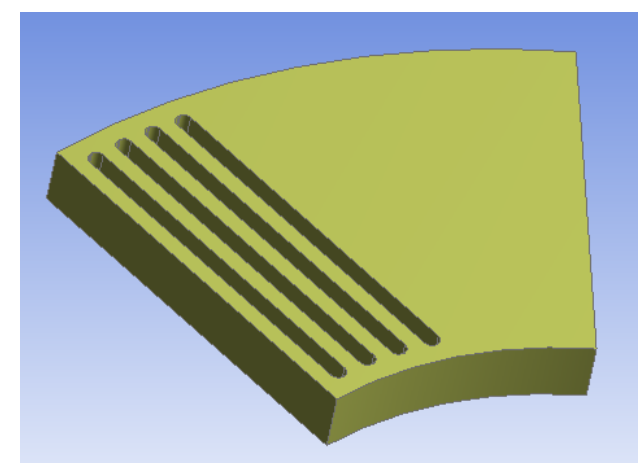

(b)

Gambar 1. (a) Model 3D textured bearing dengan tekstur, (b) permukaan diam dalam bearing yang sudah diberi tekstur

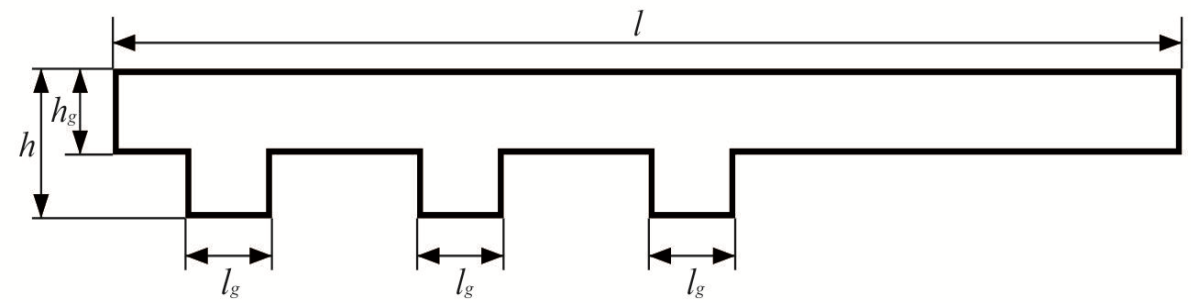

Gambar 2. Skema representasi textured bearing

Untuk keseluruhan simulasi dalam penelitian, geometri yang digunakan adalah seperti tersaji dalam Tabel 1 di bawah. Dalam penelitian ini, ada dua kedalaman tekstur yang digunakan. Kedalaman tekstur tak berdimensi $H_{d}$ didefinikan sebagai rasio antara kedalaman tekstur dengan ketebalan dasar film pelumas $h_{g} . H_{d}$ yang digunakan adalah sebesar 0.75 dan 0.1 .

Tabel 1. Data geometri bearing dengan tekstur

\begin{tabular}{|l|ll|l|l|lc|}
\hline \multicolumn{2}{|c|}{$H_{d}=0.75:$} & & \multicolumn{2}{c|}{$H_{d}=0.1:$} \\
\hline Panjang bearing & $l$ & $=6 \mathrm{~mm}$ & Panjang bearing & $l$ & $=6 \mathrm{~mm}$ \\
\hline Panjang daerah slip & $l_{s}$ & $=2.1 \mathrm{~mm}$ & & Panjang daerah slip & $l_{s}$ & $=2.1 \mathrm{~mm}$ \\
\hline Panjang tekstur & $l_{g}=0.3 \mathrm{~mm}$ & & Panjang tekstur & $l_{g}$ & $=0.3 \mathrm{~mm}$ \\
\hline Ketebalam total pelumas & $h$ & $=52.5 \mu \mathrm{m}$ & & Ketebalam total pelumas & $h$ & $=33 \mu \mathrm{m}$ \\
\hline Ketebalam dasar pelumas & $h_{g}=30 \mu \mathrm{m}$ & & Ketebalam dasar pelumas & $h_{g}$ & $=30 \mu \mathrm{m}$ \\
\hline Kedalaman tekstur & $h-h_{g}=22.5 \mu \mathrm{m}$ & & Kedalaman tekstur & $h-h_{g}$ & $=3 \mu \mathrm{m}$ \\
\hline
\end{tabular}

Mesh yang digunakan pada textured bearing ini terdiri dari tujuh blok dengan grid seragam pada masing masing tekstur. Jumlah titik grid pada arah longitudinal $\left(N_{x}\right)$ dan transversal $\left(N_{z}\right)$ adalah $900 \times 50$. Gambar 3 menyajikan pola mesh yang digunakan untuk simulasi. 


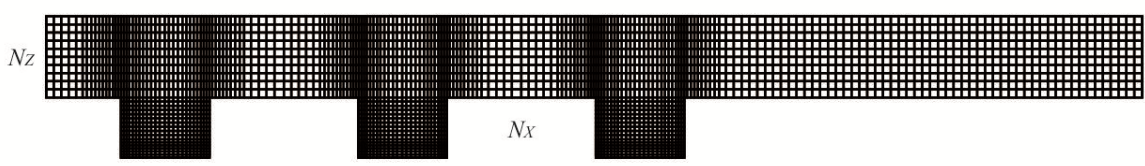

(a)

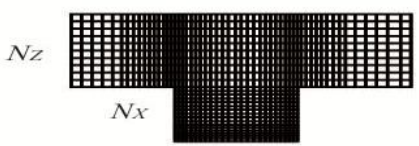

(b)

Gambar 3. Gambar struktur mesh (a) Domain komputasi, (b) pembesaran mesh pada salah satu tekstur

\subsection{Kondisi Batas dan Prosedur Solusi}

Asumsi nilai tekanan pada sisi masuk dan keluar bearing diatur nol dan gradien kecepatan bernilai nol pada arah normal terhadap sliding. Pada permukaan yang bergerak, kondisi batas no-slip diasumsikan untuk persamaan aliran, yaitu kecepatan dinilai konstan, sementara tekanan memiliki kondisi batas gradien nol. Gambar 4 menyajikan konfigurasi bearing dengan kondisi batas no-slip dan slip. Konfigurasi ini memungkinkan pengaruh pemberian slip pada textured bearing dapat diteliti apakah menguntungkan apa tidak dilihat dari performansi bearing.

moving wall with speed of $U \longrightarrow$

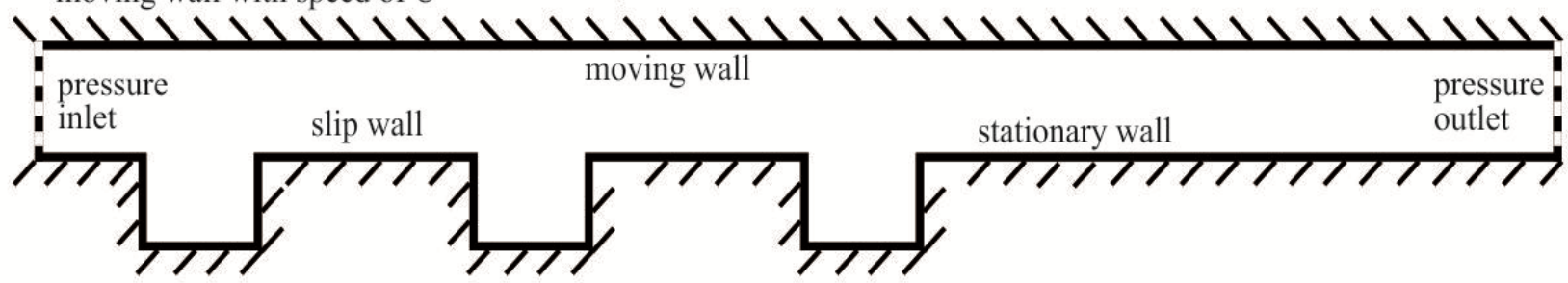

(a)

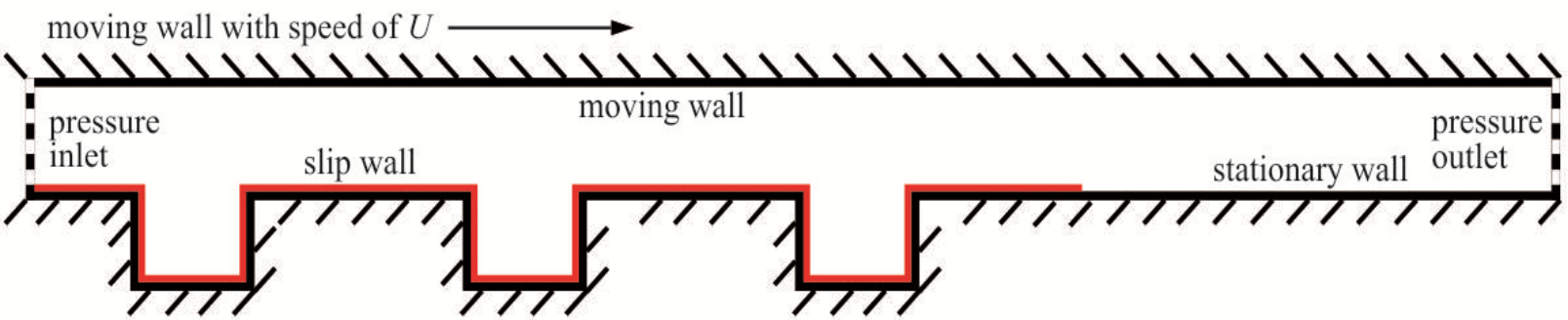

(b)

Gambar 4. Domain komputasi textured bearing untuk kondisi: (a) konvensional (tanpa slip), (b) slip

Kondisi batas yang digunakan pada kasus ini adalah:

- Kecepatan dinding atas

- Massa jenis pelumas

- Indeks konsistensi

- Indeks power-law

- Viskositas dinamis minimal pelumas

- Viskositas dinamis maksimal pelumas

- Tekanan sisi masuk

- Tekanan sisi keluar

$$
\begin{aligned}
U & =2 \mathrm{~m} / \mathrm{s} \\
\rho_{l} & =1000 \mathrm{~kg} / \mathrm{m}^{3} \\
k & =0.044 \mathrm{~kg}-\mathrm{s}^{\mathrm{n}-2} / \mathrm{m} \\
n & =0.75 \\
\eta_{\min } & =0.001 \mathrm{~kg} / \mathrm{m} . \mathrm{s} \\
\eta_{\max } & =1000 \mathrm{~kg} / \mathrm{m} . \mathrm{s} \\
P_{\text {inlet }} & =1 \mathrm{~atm} \\
P_{\text {outlet }} & =1 \mathrm{~atm}
\end{aligned}
$$

Dalam simulasi ini, kondisi slip diaplikasikan di bagian inlet untuk mendapatkan performansi daya dukung beban terbaik [16]. Di daerah inlet dan outlet domain komputasi, tekanan ditetapkan sama dengan tekanan atmosfer. Asumsi gradien kecepatan nol dalam arah normal terhadap permukaan sliding digunakan untuk merepresentasikan aliran fully developed. Model aliran turbulen $k$-e realizable dan kondisi isothermal digunakan dalam analisa ini. Skema second order upwind diaplikasikan untuk diskretisasi momentum, sedangkan prosedur SIMPLE digunakan untuk pressure-velocity coupling. 


\section{HASIL DAN PEMBAHASAN}

\subsection{Validasi}

Hal pertama yang dilakukan dalam upaya menyelesaikan suatu permasalahan analisis adalah mencari suatu pembanding. Pembanding tersebut digunakan untuk melakukan suatu pengujian kelayakan hasil, yaitu dengan membandingkan hasil-hasilnya. Dari hasil validasi, diketahui hasil perhitungan ulang telah memenuhi syarat atau tidak. Klasifikasi memenuhi syarat jika hasil sudah mendekati dengan hasil perhitungan yang telah ada di beberapa literatur yang dijadikan acuan. Dalam penelitian ini, tulisan yang dijadikan acuan adalah hasil kerja Muchammad dkk [17]. Fokus perbandingan untuk validasi adalah fenomena kavitasi dan pemodelannya secara numerik.

Tabel 2 menyajikan validasi hasil simulasi daya dukung beban (load support) seperti ditunjukkan pada Tabel 2. Dari Tabel 2 dapat diambil kesimpulan bahwa pemilihan metode numerik dan pemodelan kavitasi yang digunakan terbukti berhasil diaplikasikan dalam analisa hidrodinamika textured bearing mengingat perbedaan hasil yang relatif kecil.

Tabel 2. Validasi daya dukung beban pada slider bearing

\begin{tabular}{|l|c|c|}
\hline & $W(\mathrm{~N})$ & $P_{\max }(\mathrm{MPa})$ \\
\hline Present study & $48,050.48$ & 4.55 \\
\hline Muchammad, dkk [11] & $47,822.25$ & 4.49 \\
\hline$\Delta(\%)$ & 4.7 & 1.4 \\
\hline
\end{tabular}

\subsection{Pengaruh kedalaman dimple, slip, dan kavitasi}

Dalam penelitian ini, ada 4 kasus yang akan diteliti untuk mengeksplorasi pengaruh kedalaman dimple, kondisi batas slip dan pemodelan kavitasi. Kasus tersebut adalah (1) bearing konvensional (tanpa slip) dan tanpa kavitasi, (2) bearing konvensional dengan mempertimbangkan model kavitasi, (3) bearing dengan slip dan tanpa kavitasi, (4) bearing dengan slip dan mempertimbangkan model kavitasi. Kondisi batas slip diatur dalam bearing seperti tersaji dalma Gambar 4. Rekayasa kondisi slip ini seperti halnya pemberian tekstur sengaja dibuat di daerah inlet untuk mendapatkan performansi pelumasan maksimum.

Gambar 5 menyajikan distribusi tekanan hidrodinamik untuk keempat kasus yang diteliti dengan tidak memodelkan kavitasi. Dengan kata lain, Persamaan 4-6 tidak dihitung dalam analisa CFD. Dari Gambar 5 ini dapat dilihat bahwa tekanan maksimum terjadi pada batas antara daerah bertekstur dengan yang tidak bertekstur. Hal ini seperti yang diprediksi semula, karena seperti diketahui bersama, gradien parameter fisik (tekanan hidrodinamik dalam kasus ini) akan bernilai maksimum jika terjadi perubahan geometri / penanmpang yang ekstrim. Hal yang menarik dari hasil simulasi ini adalah bahwa pemberian slip pada permukaan bertekstur memberikan kenaikan performansi tekanan hidrodinamik yang sangat signifikan untuk semua kedalaman tekstur yang menjadi bahan kajian disini jika dibandingkan dengan textured-bearing yang konvensional. Dengan kata lain, slip memberikan pengaruh yang dominan dalam menciptakan pelumasan yang optimal. Peningkatan performansi daya dukung beban dengan adanya slip bisa mencapai 4 kali lipat dibanding bearing tanpa slip untuk semua pola tekstur.. Sedangkan jika dilihat dari aspek pengaruh kedalaman tekstur, hasil simulasi menunjukkan bahwa semakin besar kedalaman tekstur nya, semakin besar pula distribusi tekanan hidrodunamik yang terjadi baik untuk kondisi slip maupun yang konvensional (tanpa slip), yang berarti berdampak pada makin besarnya daya dukung beban (load support).

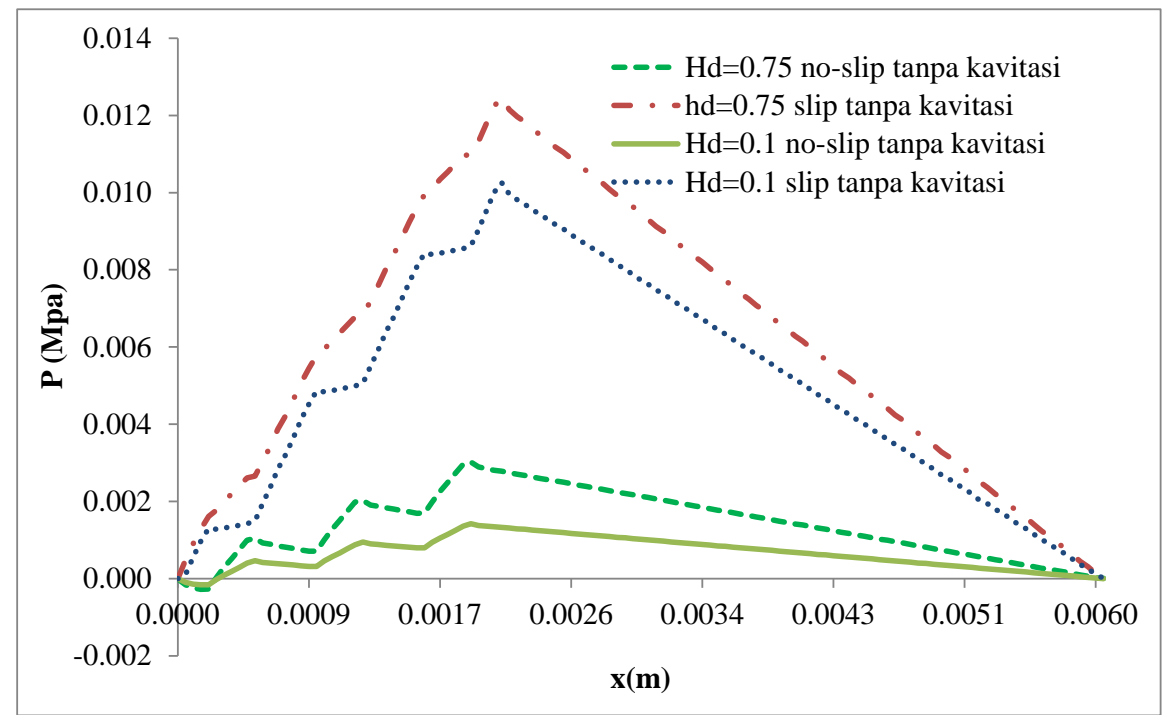

Gambar 5. Distribusi tekanan untuk keempat kasus dimana kavititasi tidak dipertimbangkan 
Gambar 6 menyajikan distribusi tekanan hidrodinamik dengan mempertimbangkan model kavitasi (Persamaan 57). Seperti halnya pada kondisi no-cavitation, pemberian slip mampu memberikan kenaikan tekanan hidrodinamik yang sangat signifikan, baik itu ketika dimple berkedalaman 0.1 maupun ketika 0.75 . Hal ini akan membawa konsekuensi terhadap kenaikan daya dukung beban. Pemberian slip pada salah satu permukaan bearing menyebabkan gradien kecepatan di tiap titik di sepanjang permukaan kontak mengalami penurunan yang berimbas naiknya gradien tekanan dan menurunnya tegangan geser. Selain itu, adanya kavitasi yang terjadi di area tertentu dalam dimple juga menyebabkan tekanan hidrodinamik menjadi lebih besar. Hal inilah yang menyebabkan mengapa prediksi tekanan hidrodunamik dan daya dukung beban ketika model kavitasi dipertimbangkan menjadi lebih besar dibandingkan ketika tanpa mempertimbangkan kavitasi. Tabel 3 menyajikan hasil perbandingan analisa CFD dengan dan tanpa melibatkan model kavitasi untuk prediksi daya dukung beban dan gesekan untuk dua kedalaman tekstur yang berbeda. Tampak jelas bahwa prediksi CFD parameter daya dukung beban maupun gesekan dengan kavitasi bisa mencapai $20 \%$ lebih besar dibanding dengan analisa tanpa model kavitasi baik untuk kondisi slip maupun tanpa slip. Dari sini dapat disimpulkan bahwa untuk analisa textured bearing, hasil yang akurat sesuai dengan kondisi fisik yang terjadi dapat dicapai bila pemodelan kavitasi dipertimbangkan dalam perhitungan.

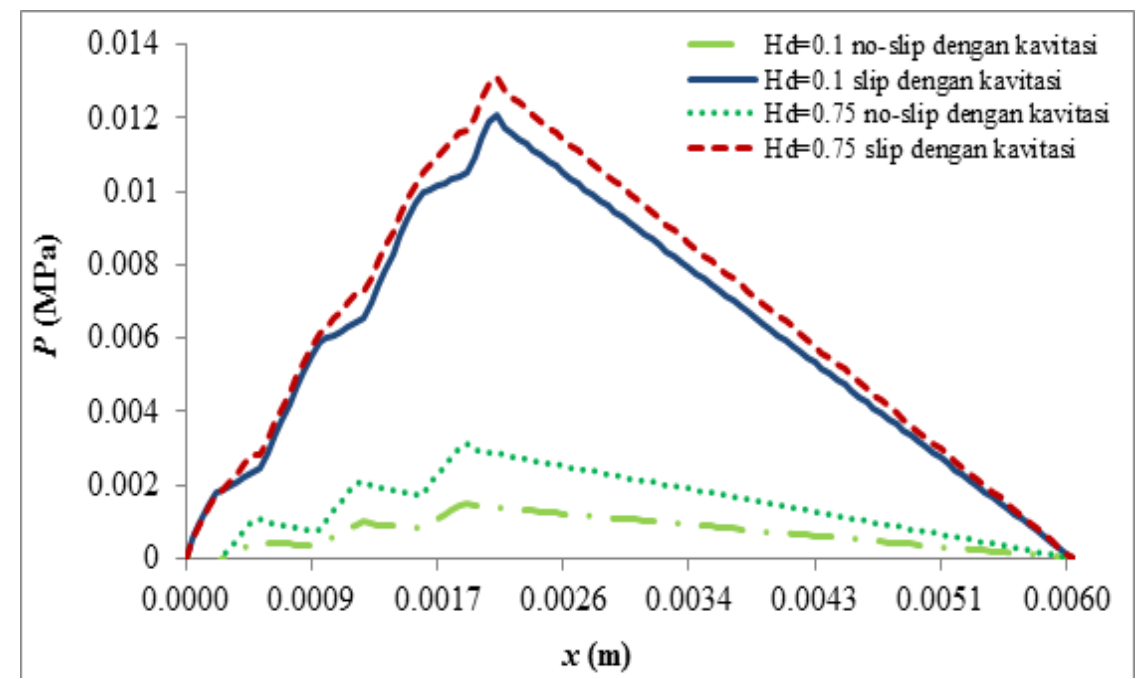

Gambar 6. Distribusi tekanan untuk keempat kasus dimana model kavititasi dipertimbangkan

Tabel 3. Perbandingan prediksi performansi pelumasan dengan dan tanpa model kavitasi

\begin{tabular}{|c|c|c|c|c|}
\hline \multirow{2}{*}{$\boldsymbol{H}_{\boldsymbol{d}}=\mathbf{0 . 7 5}$} & \multicolumn{2}{|c|}{ Slip } & \multicolumn{2}{c|}{ No-slip } \\
\cline { 2 - 5 } & $\boldsymbol{W}(\mathbf{N})$ & $\boldsymbol{F}(\mathbf{N})$ & $\boldsymbol{W}(\mathbf{N})$ & $\boldsymbol{F}(\mathbf{N})$ \\
\hline Tanpa Kavitasi & 37.28 & 1.03 & 8.34 & 1.15 \\
\hline Kavitasi & 39.29 & 1.07 & 8.58 & 1.16 \\
\hline Perbedaan (\%) & 5 & 4 & 3 & 1 \\
\hline \multirow{2}{*}{$\boldsymbol{H}_{\boldsymbol{d}}=\mathbf{0 . 1}$} & \multicolumn{2}{|c|}{ Slip } & \multicolumn{2}{c|}{ No-slip } \\
\cline { 2 - 6 } & $\boldsymbol{W}(\mathbf{N})$ & $\boldsymbol{F}(\mathbf{N})$ & $\boldsymbol{W}(\mathbf{N})$ & $\boldsymbol{F}(\mathbf{N})$ \\
\hline Tanpa Kavitasi & 30.09 & 0.92 & 3.92 & 1.15 \\
\hline Kavitasi & 36.23 & 0.98 & 4.10 & 1.16 \\
\hline Perbedaan (\%) & 20 & 7 & 5 & 1 \\
\hline
\end{tabular}

\section{KESIMPULAN}

Investigasi performansi pelumasan bearing dengan pelumas non Newtonian dilakukan dengan menggunakan analisa CFD (computational fluid dynamic). Fokus penelitian adalah pengaruh model kavitasi dan slip terhadap performansi. Kasus yang diangkat adalah textured bearing dengan dua kedalaman tekstur yang berbeda. Kesimpulan yang dapat diambil dari simulasi numerik textured bearing berpelumas non Newtonian ini adalah sebagai berikut:

1. Pemberian slip pada textured bearing memiliki pengaruh yang signifikan dalam meningkatkan daya dukung beban.

2. Mengabaikan model kavitasi dalam analisa textured bearing dapat membawa pengambilan kesimpulan yang salah. Hal ini dikarenakan perbedaan prediksi dengan dan tanpa model kavitasi dapat mencapai 20 kali lipat.

3. Pemilihan kedalaman tekstur yang tepat untuk textured bearing membawa peningkatan performansi pelumasan.

Hasil penelitian ini diharapkan dapat menjadi panduan ketika melakukan proses perancangan dan analisa bearing yang memiliki tekstur. 


\section{DAFTAR PUSTAKA}

[1] T. V. V. L. N. Rao, "Theoretical Prediction of Journal Bearing Stability Characteristics Based on the Extent of the Slip Region on the Bearing Surface,” Tribol. Trans., vol. 52, no. 6, pp. 750-758, 2009.

[2] M. J. Braun and W. M. Hannon, "Cavitation formation and modelling for fluid film bearings: a review," Proc. Inst. Mech. Eng. Part J J. Eng. Tribol., vol. 224, no. 9, pp. 839-863, 2010.

[3] P. C. Mishra, "Mathematical modeling of stability in rough elliptic bore misaligned journal bearing considering thermal and non-Newtonian effects," Appl. Math. Model., vol. 37, no. 8, pp. 5896-5912, 2013.

[4] H. G. Elrod, “A Cavitation Algorithm,” J. Lubr. Technol., vol. 103, no. 3, p. 350, Jul. 1981.

[5] S. K. Yadav and S. C. Sharma, "Performance of hydrostatic tilted thrust pad bearings of various recess shapes operating with non-Newtonian lubricant," Finite Elem. Anal. Des., vol. 87, pp. 43-55, 2014.

[6] J.-R. Lin, R.-F. Lu, L.-M. Chu, and C.-R. Hung, "The effects of non-Newtonian rheology in the dynamic coefficients of wide slider bearings with a secant-shaped film profile," Ind. Lubr. Tribol., vol. 65, no. 6, pp. 351356, Sep. 2013.

[7] A. W. Pratomo, Muchammad, M. Tauviqirrahman, Jamari, and A. P. Bayuseno, "Tribological characteristic enhancement effects by polymer thickened oil in lubricated sliding contacts," in AIP Conference Proceedings 1725, 2016, vol. 20060, p. 20060.

[8] M. Tauviqirrahman, W. K. Ajie, E. Yohana, M. Muchammad, and J. Jamari, "A Study of slip position on improving the hydrodynamic lubrication performance of single-textured bearing using a mass conserving numerical approach,” Int. J. Eng. Technol., vol. 8, no. 2, pp. 913-921, 2016.

[9] C. B. Khatri and S. C. Sharma, "Influence of textured surface on the performance of non-recessed hybrid journal bearing operating with non-Newtonian lubricant," Tribol. Int., vol. 95, pp. 221-235, 2016.

[10] M. Tauviqirrahman, Muchammad, R. Ismail, J. Jamari, and D. J. Schipper, "The Effect of a Hydrophobic Coating Material on Friction in a Micro-Slider Bearing: A Numerical Analysis," Adv. Mater. Res., vol. 1123, pp. 42-45, 2015.

[11] J. H. Choo, R. P. Glovnea, a. K. Forrest, and H. a. Spikes, “A Low Friction Bearing Based on Liquid Slip at the Wall," J. Tribol., vol. 129, no. 3, p. 611, 2007.

[12] J. H. Choo, H. A. Spikes, M. Ratoi, R. Glovnea, and A. Forrest, "Friction reduction in low-load hydrodynamic lubrication with a hydrophobic surface," Tribol. Int., vol. 40, no. 2 SPEC. ISS., pp. 154-159, 2007.

[13] ANSYS, ANSYS Fluent, version 14.0: user manual. ANSYS, Inc., Canonsburg, USA., 2011.

[14] P. Zwart, A. Gerber, and T. Belamri, "A two-phase flow model for predicting cavitation dynamics," in Fifth International Conference on Multiphase Flow, Yokohama, Japan, May 30 - June 3, 2004, no. 152.

[15] M. Tauviqirrahman, Muchammad, Jamari, and D. J. Schipper, "Numerical Study of the Load-Carrying Capacity of Lubricated Parallel Sliding Textured Surfaces including Wall Slip,” Tribol. Trans., vol. 57, no. 1, pp. 134-145, 2014.

[16] M. Tauviqirrahman, R. Ismail, J. Jamari, and D. J. Schipper, “A study of surface texturing and boundary slip on improving the load support of lubricated parallel sliding contacts," Acta Mech., vol. 224, no. 2, pp. 365-381, 2013.

[17] Muchammad, M. Tauviqirrahman, J. Jamari, and D. J. Schipper, "Load Support Improvement on Superhydrophobic Surface in Lubricated-MEMS Using Numerical Investigation,” Adv. Mater. Res., vol. 1123, pp. 3-6, 2015. 